\title{
OPEM
}

www.opem.org

Oriental Pharmacy and Experimental Medicine 2009 9(1), 74-82

DOI 10.3742/OPEM.2009.9.1.074

\section{Anti-inflammatory activity of aqueous methanolic extract of Swietenia mahagoni (L.) Jacq. (Meliaceae) leaves}

\author{
Roy $\mathbf{S}^{1}$, Besra $\mathrm{SE}^{1}$, Banerjee $\mathrm{B}^{2}$, Mukherjee $\mathrm{J}^{3}$ and Vedasiromoni $\mathbf{J R}^{1, *}$ \\ ${ }^{1}$ Drug Development Division, Indian Institute of Chemical Biology, 4, Raja S.C. Mullick Road, Kolkata-700032, \\ India; ${ }^{2}$ Department of Chemistry, K.N.College, Berhampur-742101, India; ${ }^{3}$ Department of Life Science \& \\ Biotechnology, Jadavpur University, Kolkata-700032, India
}

Received for publication November 22, 2007; accepted November 25, 2008

\begin{abstract}
SUMMARY
Pharmacological investigations were carried out with aqueous methanolic extract (AME) of Swietenia mahagoni (L.) Jacq. (Meliaceae) leaves. Acute toxicity studies revealed that the $\mathrm{LD}_{50}$ dose of AME was $600 \mathrm{mg} / \mathrm{kg}$, i.p. AME was found to possess significant anti-inflammatory activity in acute, sub-chronic and chronic models of inflammation. AME selectively inhibited cyclooxygenase (COX)-2 activity, which is involved in arachidonic acid metabolism and biosynthesis of prostaglandins under inflammatory conditions. Treatment with AME significantly enhanced total peritoneal cell count and the number of macrophages in normal mice, which revealed that AME may also alter the immune response along with its anti-inflammatory effect. The saponins or the alkaloids present in AME may be responsible for the anti-inflammatory activity.
\end{abstract}

Key words: Swietenia mahagoni leaf; Anti-inflammatory activity; Cyclooxygenase-2 inhibition

\section{INTRODUCTION}

Leaves of medicinal plants are common ingredients of many folk and herbal medicines (Subapriya and Nagini, 2005; Guo et al., 2006) and leaf extracts of a number of medicinal plants have been reported to possess pharmacological activity, including anti-inflammatory activity (Ojewole, 2005; Owoyele et al., 2005; Sertie et al., 2005). Swietenia mahagoni (L.) Jacq. (Meliaceae) is a humid zone species, with natural distribution in the Caribbean region, and has been extensively planted

*Correspondence: Joseph Rajan Vedasiromoni, Drug Development Division, Indian Institute of chemical Biology, 4, Raja S.C. Mullick Road, Kolkata-700032, India. Tel: 91-33-2473-3491/0492/3493/6793 Extn. 108; Fax: 91-33-2473-0284/5197; E-mail: j_rajan_49@yahoo.com in South Asia and in the pacific. It is an evergreen to semi-evergreen tree of $30-35 \mathrm{~m}$ height. The leaves are clustered, glabrous, $12-15 \mathrm{~cm}$ long, peripinnately compound with 2 - 4 pairs of leaflets (ovate-lanceolate, 5 - $6 \mathrm{~cm}$ long, 2 - $3 \mathrm{~cm}$ wide, dark green, glabrous). The tree has potential use for large-scale timber production due to its excellent timber quality. It is also used in agro forestry for soil improvement and as an ornamental tree (Schmidt and Joker, 2000). The seeds of this plant have been reported to contain triterpenoids possessing anti-platelet activity and anti-microbial activity (Ekhimoto et al., 1991). Since the plant belongs to the same Meliaceae family as neem (Azadirachta indica), it is expected that it might also be a storehouse of many chemicals of medicinal and pharmacological interest. The purpose 
of the present work was to investigate the mechanism of anti-inflammatory activity of aqueous methanolic extract (AME) of Swietenia mahagoni (L.) Jacq. leaves.

\section{MATERIALS AND METHODS}

\section{Plant material}

The leaves of Swietenia mahagoni (L.) Jacq. were collected by local supplier from sites around Kolkata, India, during June, 2006. The plant was identified by Indian Botanical Garden, Howrah, India, where a voucher specimen (SR-001) has been kept.

\section{Extraction and preparation of test sample}

One $\mathrm{kg}$ of leaves of Swietenia mahagoni (L.) Jacq. were sun dried, ground and soaked in three liters of $50 \%$ aqueous methanol for one week at room temperature $\left(28-34^{\circ} \mathrm{C}\right)$ with occasional shaking (Ekpendu et al., 1994; Manga et al., 2004; Gulfraz et al., 2006). The supernatant was filtered and to the residue 1 liter of $50 \%$ aqueous methanol was added and kept for another one week. The methanol portion in the whole supernatant was evaporated using a rotary evaporator and then it was lyophilized to remove the water. The solid dark brown residue ( $30 \mathrm{~g}$ ) thus obtained was designated as 'AME' and was kept at $4{ }^{\circ} \mathrm{C}$. To make a stock solution, $100 \mathrm{mg}$ of the AME was dissolved in $1 \mathrm{ml}$ distilled water from which different suitable doses were prepared for intraperitoneal administration to different experimental animals.

\section{Phytochemical screening}

AME was screened qualitatively for various constituents like alkaloids, steroids, flavonoids, saponins, reducing sugars, tannins and anthraquinones using established methods (Okerulu and Ani, 2001).

\section{Animals}

Experiments were performed on albino (Sprague Dawley strain) rats weighing $100-125 \mathrm{~g}$ and Balb $\mathrm{C}$ mice weighing $20-25 \mathrm{~g}$. The animals were bred in the institute's animal house and were housed under conditions of $24 \pm 2{ }^{\circ} \mathrm{C}$ and $55-60 \%$ relative humidity and $12 \mathrm{~h}$ light and $12 \mathrm{~h}$ dark cycle. During maintenance, the animals received a diet of food pellets (fortified with minerals and vitamins) prepared in the animal house and water ad libitum. All animal studies were carried out after getting clearance from Institute animal ethics committee.

\section{Chemicals}

Arachidonic acid, carrageenan, croton oil, Freund's complete adjuvant, ibuprofen and indomethacin were purchased from Sigma; acetic acid from E. Merck; phenidone from Biomol Co; COX inhibitor screening assay kit and Lipoxygenase inhibitor screening assay kit from Cayman chemical; Biotrak enzyme immunoassay kit RPN222 and Biotrak enzyme immunoassay kit RPN221 from Amersham Biosciences Inc. and all other chemicals were of analytical grade purchased locally.

\section{Acute toxicity studies}

Different doses of AME (50 mg to $1 \mathrm{~g} / \mathrm{kg}$ ) were administered intraperitoneally to groups of mice $(\mathrm{n}=10)$. The $\mathrm{LD}_{50}(24 \mathrm{~h})$ was calculated according to Ghosh (1984).

\section{Anti-inflammatory studies}

\section{Acute models}

\section{Carrageenan induced paw oedema in rats}

The animals were divided into five groups $(n=6)$. The first group served as negative control and received normal saline $(0.1 \mathrm{ml} / 100 \mathrm{~g}$, i.p. $)$, the second group was administered the standard drug, ibuprofen $(100 \mathrm{mg} / \mathrm{kg}$, i.p.), the other three groups received AME at doses of 30, 60 and 120 $\mathrm{mg} / \mathrm{kg}$, i.p. respectively. Thirty minutes later oedema was induced by injecting carrageenan $(0.1 \mathrm{ml} / 100 \mathrm{~g}$ from a $10 \mathrm{mg} / \mathrm{ml}$ solution) into the plantar aponeurosis of right hind paw of each rat (Winter et al., 1962). The left hind paw served as the control. After $4 \mathrm{~h}$, the rats were sacrificed by cervical dislocation and the paw volume was 
measured using a plethysmometer (UGO BASILE) and in each case the volume of the right hind paw was compared with that of the corresponding left hind paw.

\section{Croton oil induced ear inflammation in mice}

Croton oil irritant solution prepared according to Brooks et al. (1985) was applied $(0.1 \mathrm{ml})$ to the inner surface of the right ear of each animal. The mice were divided into five groups $(n=6)$. The first group served as negative control and received 0.1 $\mathrm{ml} / 10 \mathrm{~g}$ of normal saline, the animals of the second group received ibuprofen $(100 \mathrm{mg} / \mathrm{kg}$, i.p.) and mice of groups three, four and five were given 30, 60 and $120 \mathrm{mg} / \mathrm{kg}$, i.p. of AME respectively $30 \mathrm{~min}$ before the application of croton oil. After $4 \mathrm{~h}$ the mice were sacrificed by cervical dislocation and $7 \mathrm{~mm}$ punches were made in the ears of all the animals using a cork borer. The weight of each ear disc was measured and comparisons were done with that of the control group.

\section{Sub-chronic model}

Cotton pellet induced granuloma formation in rats Two autoclaved cotton pellets, each weighing $10 \pm$ $1 \mathrm{mg}$, were implanted subcutaneously into both sides of the groin region of each rat (D'Arcy et al., 1960). The animals were divided into five groups $(n=6)$. The first group served as negative control and received normal saline daily at a dose of 0.1 $\mathrm{ml} / 100 \mathrm{~g}$ body weight i.p. for 7 days, the second group received ibuprofen daily at a dose of 100 $\mathrm{mg} / \mathrm{kg}$, i.p for 7 days and AME at doses of 30, 60, $120 \mathrm{mg} / \mathrm{kg}$, i.p were injected daily into the rats of groups 3, 4 and 5 respectively for 7 days. After 7 days the rats were sacrificed by cervical dislocation, the cotton pellets along with the granuloma tissues were carefully taken out, dried in an oven at $60^{\circ} \mathrm{C}$, weighed and compared with control (D'Arcy et al., 1960).

\section{Chronic model}

Freund's adjuvant induced polyarthritis in rats
The rats were divided into five groups $(n=6) .0 .1$ $\mathrm{ml}$ of Freund's complete adjuvant was injected into the plantar pads of each animal on day 1 . While the first group served as the negative control and received $0.1 \mathrm{ml} / 100 \mathrm{~g}$, i.p. normal saline, those of the second group received the standard drug ibuprofen at a dose of $100 \mathrm{mg} / \mathrm{kg}$, i.p. and the rats of groups 3, 4 and 5 were injected with AME at doses of 30,60 and $120 \mathrm{mg} / \mathrm{kg}$, i.p. respectively for 21 consecutive days. The paw volume of each rat was measured on day 0 before adjuvant administration and on day 21 after treatment using plethysmometer (UGO BASILE). Inhibition in inflammation was thereby calculated. Severity and development of secondary lesions were also compared (Newbould, 1963).

\section{Possible mechanism of action}

\section{Arachidonic acid induced paw oedema in rats}

The animals were divided into six groups $(n=6)$. Group I served as negative control and received 0.1 $\mathrm{ml} / 100 \mathrm{~g}$, i.p. of normal saline, group II received the standard cyclooxygenase blocker, indomethacin (10 mg/ $\mathrm{kg}$, p.o.), group III received the standard dual blocker, phenidone $(200 \mathrm{mg} / \mathrm{kg}$, i.p.) and the other three groups were given AME at doses of 30, 60 and $120 \mathrm{mg} / \mathrm{kg}$, i.p. respectively. Paw oedema was induced by single injection of $0.1 \mathrm{ml}$ of $0.5 \%$ arachidonic acid in $0.2 \mathrm{M}$ carbonate buffer ( $\mathrm{pH} 8.4$ ) into the right hind paw (sub plantar) of each rat $1 \mathrm{~h}$ after drug and AME administration. Hind paw volume was measured in each case one $h$ after arachidonic acid injection (DiMartino et al., 1987).

\section{Determination of COX-1 and COX-2 enzyme inhibitory} activity in cell free system

The COX-1 (ovine) and COX-2 (human recombinant) inhibitory assay was carried out using a COX Inhibitor Screening Assay Kit (Cayman Chemicals) according to the manufacturer's protocol. Briefly, COX enzymes, COX-1 and COX-2, respectively and heme were added to test tubes containing COX reaction buffer (0.1 M Tris-HCl, $\mathrm{pH} 8.0$, containing 5 mM EDTA 
and $2 \mathrm{mM}$ phenol). The mixture was vortexed and exposed to either reaction buffer or different concentrations of AME and incubated for $10 \mathrm{~min}$ at $37^{\circ} \mathrm{C}$. Subsequently, to initiate the reaction, arachidonic acid solution was added, vortexed and incubated for $2 \mathrm{~min}$ at $37^{\circ} \mathrm{C}$. $\mathrm{HCl}(1 \mathrm{M})$ was then added to stop the enzyme catalysis followed by chemical reduction of prostaglandin (PG) PGH2 to PGF2 $\alpha$ with saturated stannous chloride solution for $5 \mathrm{~min}$ at room temperature. The $\mathrm{COX}$ activity was measured based on the amount of PGF2 $\alpha$ generated in the reaction tube and detected by the enzyme immunoassay (EIA) kit using a standard curve. The COX-1 and COX-2 enzyme inhibitory activities of AME were thereby determined.

\section{Determination of LOX enzyme inhibitory activity in cell free system}

The 15-lipoxygenase (soybean) inhibition assay was carried out using a Lipoxygenase Inhibitor Screening Assay Kit (Cayman Chemicals), according to the manufacturer's protocol. Briefly, 15-LO was exposed to assay buffer (0.1 M Tris-HCl, $\mathrm{pH} 7.4$ ) or different concentrations of AME. Arachidonic acid was added to start the reaction and kept on a shaker for $5 \mathrm{~min}$. Chromogen was added to stop enzyme catalysis and develop the reaction. After 5 $\mathrm{min}$, the absorbance was read at $490 \mathrm{~nm}$ and the LOX enzyme inhibitory activity of AME was thereby calculated.

\section{Human whole blood assay \\ COX-1 assay [determination of thromboxane B2 (TxB2) production]}

Blood $(5 \mathrm{ml})$ was collected from a healthy male volunteer of 28 years into vacutainers containing no anticoagulants. Whole blood was dispensed into glass tubes containing AME or DMSO. The tubes were transferred to an incubator, and the blood was allowed to clot $\left(37^{\circ} \mathrm{C}, 95 \%\right.$ air, $\left.5 \% \mathrm{CO}_{2}\right)$. After $30 \mathrm{~min}$., blood clots were released from the walls of the tubes and incubated for a further 30 min. Serum was separated by centrifugation at
$3000 \mathrm{rpm}$ for $10 \mathrm{~min}$. Levels of Thromboxane B2 (TxB2) were determined by EIA (Biotrak enzyme immunoassay kit RPN221 from Amersham Biosciences Inc.) according to manufacturer's protocol.

\section{COX-2 assay (determination of PGE2 Production)} Heparinized blood (collected from the same donor) was immediately divided into aliquots and was incubated with aspirin $(100 \mu \mathrm{M})$ for $6 \mathrm{~h}$ at $37^{\circ} \mathrm{C}$ to allow aspirin to inactivate COX-1 irreversibly. Further incubation in the presence or absence of LPS (10 $\mu \mathrm{g} / \mathrm{ml}), \mathrm{DMSO}$ or AME was done for $18 \mathrm{~h}$ at $37^{\circ} \mathrm{C}$. Plasma was separated by centrifugation at 3000 rpm for $10 \mathrm{~min}$. Plasma PGE2 levels were determined by EIA (Biotrak enzyme immunoassay kit RPN222 from Amersham Biosciences Inc.) according to manufacturer's protocol.

\section{Effect of extract on normal peritoneal cells}

Ninety six mice were divided into four groups of 24 mice in each group. While group I received 0.1 $\mathrm{ml} / 10$ g, i.p. normal saline, groups II, III and IV received 30, 60 and $120 \mathrm{mg} / \mathrm{kg}$, i.p.of AME respectively. Total peritoneal exudate cells were counted from each group (6 mice at a time) at 6, 12, 24 and $48 \mathrm{~h}$ of treatment and compared (Hudson and Hay, 1989). The number of phagocytes was also determined by staining with $1 \%$ neutral red solution using a haemocytometer (Hudson and Hay, 1989).

\section{Statistical analysis}

Data are reported as arithmetic mean \pm S.E.M. Statistical analysis was done by one way analysis of variance (ANOVA) followed by Dennett's test or by Student's $t$-test. A probability value of less than 0.05 was chosen as the criterion of statistical significance.

\section{RESULTS}

\section{Phytochemical screening}

AME showed positive reactions for alkaloids, saponins and reducing sugars but tested negative for steroids, flavonoids, tannins and anthraquinones. 


\section{Acute toxicity studies}

The $\mathrm{LD}_{50}$ of $\mathrm{AME}$ was found to be $600 \mathrm{mg} / \mathrm{kg}$, i.p.

\section{Anti-inflammatory studies}

\section{Acute models}

\section{Carrageenan induced paw oedema in rats}

AME significantly inhibited carrageenan induced paw oedema as compared to control. A dose-dependent inhibition in inflammation was observed which was comparable with the standard antiinflammatory drug, ibuprofen. The percent inhibition produced by AME at doses of 30, 60 and $120 \mathrm{mg} / \mathrm{kg}$, i.p. were $76 \%, 85 \%$ and $89 \%$ respectively (Table 1).

\section{Croton oil induced ear inflammation in mice}

AME at doses of 60 and $120 \mathrm{mg} / \mathrm{kg}$, i.p. significantly inhibited ear inflammation comparable with ibuprofen. Reduction in inflammation caused by the lowest dose i.e., $30 \mathrm{mg} / \mathrm{kg}$, i.p. of AME used in the study was found to be statistically insignificant (Table 1).

\section{Sub chronic model}

Cotton pellet induced granuloma formation in rats AME significantly inhibited the granuloma formation in a dose-dependent manner. When compared to control, the percent inhibition of the increase in dry weight of cotton pellet granuloma were 52\%, 59\% and $60 \%$ at doses of 30,60 and $120 \mathrm{mg} / \mathrm{kg}$, i.p. of AME respectively and this inhibition was more than the $36 \%$ inhibition produced by ibuprofen (Table 1).

\section{Chronic model}

\section{Freund's adjuvant induced polyarthritis in rats}

Treatment with AME at doses of 30,60 and 120 $\mathrm{mg} / \mathrm{kg}$, i.p. significantly inhibited the development of arthritis by $63 \%, 81 \%$ and $83 \%$ respectively in a dose-dependent way whereas ibuprofen reduced the development of arthritis by $66 \%$ as compared to control (Table 1). When comparisons were made with that of control, it was found that the formation of secondary lesions like tail and ear nodes was also inhibited after treatment with AME for consecutive 21 days.

\section{Possible mechanism of action}

Arachidonic acid induced paw oedema in rats Treatment with the dual blocker, phenidone (200 $\mathrm{mg} / \mathrm{kg}$, i.p.) significantly inhibited arachidonic

Table 1. Effect of AME on four different models of inflammation

\begin{tabular}{cccccc}
\hline $\begin{array}{c}\text { Treatment } \\
\text { group }\end{array}$ & $\begin{array}{c}\text { Dose } \\
(\mathrm{mg} / \mathrm{kg} \text { i.p) }\end{array}$ & $\begin{array}{c}\text { Carrageenan induced Croton oil induced ear Increase in cotton } \\
\text { paw oedema }(\mathrm{ml})\end{array}$ & $\begin{array}{c}\text { Freund's adjuvant } \\
\text { inflammation }(\mathrm{mg})\end{array}$ & $\begin{array}{c}\text { pellet wt. }(\mathrm{mg}) \\
\text { induced arthritis }(\mathrm{ml})\end{array}$ \\
\hline N.Saline & Control & $4.75 \pm 0.33$ & $10.6 \pm 2.53$ & $49.44 \pm 3.63$ & $3.42 \pm 0.54$ \\
Ibuprofen & 100 & $1.14 \pm 0.21^{*}$ & $8 \pm 0.40^{*}$ & $31.63 \pm 1.66^{*}$ & $1.67 \pm 0.28^{*}$ \\
AME & 30 & $1.14 \pm 0.09^{*}$ & $10.2 \pm 0.18$ & $23.6 \pm 1.50^{*}$ & $1.25 \pm 0.28^{*}$ \\
AME & 60 & $0.71 \pm 0.10^{*}$ & $8.5 \pm 0.61^{*}$ & $20.43 \pm 1.76^{*}$ & $0.67 \pm 0.21^{*}$ \\
AME & 120 & $0.5 \pm 0.11^{*}$ & $6.7 \pm 0.59^{*}$ & $19.8 \pm 2.90^{*}$ & $0.58 \pm 0.08^{*}$ \\
\hline
\end{tabular}

Data are mean \pm S.E.M. *denotes significant inhibition as compared to control $(P<0.05)$.

Table 2. Effect of AME on arachidonic acid induced paw oedema in rats

\begin{tabular}{ccc}
\hline Treatment group & Dose & Arachidonic acid induced paw oedema (difference in paw volume in $\mathrm{ml}$ ) \\
\hline N.Saline & $0.1 \mathrm{ml} / 100$ g, i.p. & $3.75 \pm 0.25$ \\
Indomethacin & $10 \mathrm{mg} / \mathrm{kg}$, p.o. & $2 \pm 0.45^{*}$ \\
Phenidone & $200 \mathrm{mg} / \mathrm{kg}$, i.p. & $0.75 \pm 0.14^{*}$ \\
AME & $30 \mathrm{mg} / \mathrm{kg}$, i.p. & $1.75 \pm 0.32^{*}$ \\
AME & $60 \mathrm{mg} / \mathrm{kg}$, i.p. & $1.5 \pm 0.4^{*}$ \\
AME & $120 \mathrm{mg} / \mathrm{kg}$, i.p. & $0.875 \pm 0.239^{*}$ \\
\hline
\end{tabular}

Data are mean \pm S.E.M. * denotes significant inhibition as compared to control $(P<0.05)$. 
acid induced paw oedema in rats by $80 \%$ whereas indomethacin, the cyclooxygenase blocker, inhibited oedema formation by only $47 \%$. The percent inhibition in oedema formation produced by treatment with 30, 60 and $120 \mathrm{mg} / \mathrm{kg}$, i.p. of AME were $53 \%, 60 \%$ and $77 \%$ respectively (Table 2 ). The degree of reduction in inflammation produced by 30 and 60 $\mathrm{mg} / \mathrm{kg}$, i.p. of AME were similar to that produced by indomethacin (Table 2).

\section{Determination of COX-1 and COX-2 enzyme inhibitory activity in cell free system}

The experiments showed that AME does not have any COX-1 inhibitory activity but significantly inhibited the enzymatic activity of COX-2. The percent COX2 inhibition produced by 5, 10,15 $\mu \mathrm{g} / \mathrm{ml}$ of AME were $50 \%, 57 \%$ and $64 \%$ respectively (Table 3 ).

Determination of LOX enzyme inhibitory activity in cell free system

AME was found to possess insignificant LOX inhibitory activity.

\section{Human whole blood assay}

COX-1 assay (determination of thromboxane B2 (TxB2) production)
The percent inhibitions of Thromboxane B2 (TxB2) production in serum samples, as a reflection of COX-1 inhibition, were calculated and insignificant results were obtained.

\section{COX-2 assay (determination of PGE2 Production)}

The percent reduction in PGE2 Production (reflecting the percent COX-2 inhibition) in the $5,10,15 \mu \mathrm{g} / \mathrm{ml}$ AME treated plasma samples were $13 \%, 21 \%$ and $30 \%$ respectively (Table 3 ).

\section{Effect of extract on normal peritoneal cells}

AME treatment enhanced the number of macrophages significantly after $6,12,24$ and $48 \mathrm{~h}$ (Table 4 ). The maximum enhancement in the cell count was observed between 12-24 h after AME administration (Table 4). Similar enhancement in the number of normal peritoneal cells was also observed (Data not shown).

\section{DISCUSSION}

The study revealed that the AME of Swietenia mahagoni leaves possesses potent anti-inflammatory activity at three different doses of 30, 60 (1/10th of the $\mathrm{LD}_{50}$ value) and $120 \mathrm{mg} / \mathrm{kg}$, i.p. in rodents.

Table 3. Effect of AME on enzymatic activities of COX-1 and COX-2

\begin{tabular}{cccccc}
\hline \multirow{2}{*}{$\begin{array}{c}\text { Treatment } \\
\text { group }\end{array}$} & $\begin{array}{c}\text { Concentration } \\
(\mathrm{mg} / \mathrm{ml})\end{array}$ & \multicolumn{2}{c}{$\begin{array}{c}\text { Cell free system } \\
\text { \% Inhibition }\end{array}$} & \multicolumn{2}{c}{$\begin{array}{c}\text { Human whole blood assay \% Inhi- } \\
\text { bition }\end{array}$} \\
\cline { 3 - 6 } & & COX-1 & COX-2 & COX-1 & COX-2 \\
\hline AME & 5 & NI & $50 \pm 0.0365^{*}$ & NI & $13 \pm 0.0035$ \\
AME & 10 & NI & $57 \pm 0.061^{*}$ & NI & $21 \pm 0.008$ \\
AME & 15 & NI & $64 \pm 0.048^{*}$ & NI & $30 \pm 0.008^{*}$ \\
\hline
\end{tabular}

NI means no inhibition.

Data are mean \pm S.E.M. *denotes significant inhibition as compared to control $(P<0.05)$.

Table 4. Effect of AME on macrophage cell count in mice

\begin{tabular}{cccccc}
\hline \multirow{2}{*}{$\begin{array}{c}\text { Treatment } \\
\text { group }\end{array}$} & $\begin{array}{c}\text { Dose } \\
\text { (i.p.) }\end{array}$ & \multicolumn{4}{c}{ Number of macrophages $\times 104$} \\
\cline { 3 - 6 } & $6.1 \mathrm{ml} / 10 \mathrm{~g}$ & $122 \pm 10.51$ & $120 \pm 9.87$ & $123 \pm 10.23$ & $119 \pm 9.26$ \\
N.Saline & $30 \mathrm{mg} / \mathrm{kg}$ & $240 \pm 23.17^{*}$ & $240 \pm 26.21^{*}$ & $448 \pm 14.66^{*}$ & $312 \pm 16.47^{*}$ \\
AME & $60 \mathrm{mg} / \mathrm{kg}$ & $254 \pm 28.27^{*}$ & $254 \pm 25.47^{*}$ & $686 \pm 12.29^{*}$ & $412 \pm 8.0^{*}$ \\
AME & $120 \mathrm{mg} / \mathrm{kg}$ & $400 \pm 16.22^{*}$ & $400 \pm 27.40^{*}$ & $696 \pm 19.61^{*}$ & $424 \pm 17.6^{*}$ \\
AME &
\end{tabular}

Data are mean \pm S.E.M. *denotes significant inhibition as compared to control $(P<0.05)$. 
A series of experiments proved that AME possesses anti-inflammatory activity comparable to that produced by the standard anti-inflammatory drug, ibuprofen, in acute (carrageenan induced paw oedema in rats and croton oil induced ear inflammation in mice), sub-chronic (cotton pellet induced granuloma formation in rats) and chronic (Freund's adjuvant induced polyarthritis in rats) models of inflammation. The finding that AME significantly reduced inflammation in Freund's adjuvant induced polyarthritis in rats shows that AME has antiarthritic activity as well. In vivo experiments showed that the reduction in oedema formation was similar to that of indomethacin in the arachidonic acid induced paw oedema model in rats, indicating that AME might inhibit inflammation by blocking the cyclooxygenase pathway of arachidonic acid metabolism. In vitro studies confirmed the selective cyclooxygenase-2 inhibitory activity of AME. It is interesting to note that in all the models of inflammation AME produced the activity in a dose-dependent manner. Experiments were performed to see the effect of AME on normal murine peritoneal cells. Normally it is found that $50 \%$ of the murine intraperitoneal cells are macrophages. Injection of certain materials like casein, Freund's complete adjuvant, thioglycolate, starch, etc. leads to non-specific accumulation of macrophages in the peritoneal cavity. Mature macrophages in the untreated peritoneal cavity are mostly residential. Intraperitoneal administration of different agents results in the exudation and intraperitoneal accumulation of new macrophages, which differ, from the mature macrophages. It has been reported that the exudate macrophages are more active than the residential mature ones in their ability to spread on the surface to which the cells are attached, receptor size of the cell coat, response to chemotactic stimuli, composition of cell wall, etc. (Den Otter et al., 1982). In the present study AME treatment significantly enhanced the peritoneal cell count and also the number of macrophages. Though the actual role of AME in the enhancement of cell count can not be explained right now, it is possible that the pharmacological effects observed with AME are mediated through changes in the immune system. However, experiments need to be performed to substantiate such a possibility.

It is well known that there is a close relationship between inflammation and cancer (Thun et al., 1991; DuBois, 1995; DuBois et al., 1996). It has been reported that tumor promoters recruit inflammatory cells to the application site and cancer development may also act by aggravating inflammation in the tissue and vice versa and that inflammatory cells are capable of inducing genotoxic effects (Rosin et al., 1994). At the molecular level, products of inflammation, including free radicals, cytokines, growth factors and transcription factors (such as nuclear factor-kappa B) control the expression of cancer genes (e.g., suppressor genes and oncogenes) and key inflammatory enzymes such as cyclooxygenase-2 (COX-2) and inducible nitric oxide synthase (iNOS). So, it is likely that anti-inflammatory agents may possess anti-cancer activity and vice versa. Since the present study indicates that the extract has significant anti-inflammatory activity, it is plausible that it may possess anti-cancer activity as well. Moreover, suppression of prostaglandin biosynthesis through selective inhibition of cyclooxygenase (COX)-2 activity is now regarded as an important cancer chemopreventive strategy (Ozaki et al., 1989, Noble, 1990; Chen et al., 2000; Munos et al., 2000) and the present observation of the extract blocking COX-2 pathway of arachidonic acid metabolism provides further support for such a contention that AME may also have anti-cancer properties. The phytochemical analyses performed in the present study demonstrated that alkaloids, saponins and reducing sugars are present in AME. Alkaloids (Wang and Xie, 1999) and saponins (Sparg et al., 2004) have been referenced as antiinflammatory compounds, a fact, which could explain the anti-inflammatory activity produced by AME. 


\section{ACKNOWLEDGEMENTS}

The work was funded by University Grants Commission, India under Minor Research Project Scheme.

\section{REFERENCES}

Brooks RR, Bonk KR, Decker GE, Miller KE. (1985) Antiinflammatory activity of orpanoxin administered orally and topically to rodents. Agents Actions 16, 369-376.

Chen PS, Li JH, Liu TY, Lin TC. (2000) Folk medicine Terminalia catappa and its major tannin component, punicalagin, are effective against bleomycin-induced genotoxicity in Chinese hamster ovary cells. Cancer Lett. 152, 115-122.

D'Arcy PF, Haward EM, Muggleton PW, Townsend SB. (1960) The anti-inflammatory action of griseofulvin in experimental animals. J. Pharm. Pharmacol. 12, 659-665.

Den Otter W, De Groot JW, Van Basten CD, Rademakers LH, De Wager RA, Pels E. (1982) Brewer thioglycollate medium induces different exudates in guinea pigs and mice. Exp. Mol. Pathol. 36, 403-413.

DiMartino MJ, Campbell GK Jr, Wolff CE, Hanna N. (1987) The pharmacology of arachidonic acid-induced rat paw oedema. Agents Actions 21, 303-305.

DuBois RN. (1995) Nonsteroidal anti-inflammatory drug use and sporadic colorectal adenomas. Gastroenterol. 108, 1310-1314.

DuBois RN, Giardiello FM, Smalley WE. (1996) Nonsteroidal anti-inflammatory drug eicosanoids and colorectal cancer prevention. Gastroenterol. Clin. North Am. 24, 773-791.

Ekimoto H, Irie Y, Araki Y, Han GQ, Kadota S, Kikuchi T. (1991) Platelet aggregation inhibitors from the seeds of Swietenia mahagoni: inhibition of in vitro and in vivo platelet-activating factor-induced effects of tetranortriterpenoids related to swietenine and swietenolide. Planta Med. 57, 56-58.

Ekpendu TO, Akah PA, Adesomoju AA, Okogun JI. (1994) Antiinflammatory and antimicrobial activities of Mitracarpus scaber extracts. Int. J. Pharmacog. 32, 191-196.

Ghosh MN. (1984) Fundamentals of experimental pharmacology, second ed. Scientific Book Agency, Calcutta, India.

Gulfraz M, Waheed A, Mehmood S, Ihtisham M. (2006) Extraction and Purification of various Organic Compounds in Selected Medicinal Plants of Kotli Sattian, District Rawalpindi, Pakistan. Ethnobotanical Leaflets 10, 13-23.

Guo R, Pittler MH, Ernst E. (2006) Herbal medicines for the treatment of COPD: a systematic review. Eur. Resp. J. 28, 330-338.

Hudson L, Hay FC. (1989) Practical Immunology. Oxford: Blackwell, Oxford.

Manga M, Brkic D, Marie DEP, Quetin-Leclercq J. (2004) In vivo anti-inflammatory activity of Alchornea cordifolia (Schumach. \& Thonn.) Mull. Arg. (Euphorbiaceae) J. Ethnopharmacol. 92, 209-214.

Munoz V, Sauvain M, Bourdy G, Callapa J, Rojas I, Vargas L, Tae A, Deharo E. (2000) The search for natural bioactive compounds through a multidisciplinary approach in Bolivia. Part II. Antimalarial activity of some plants used by Mosetene Indians. J. Ethnopharmacol. 69, 139-155.

Newbould BB. (1987) Chemotherapy of arthritis induced in rats by mycobacterial adjuvant. Brit. J. Pharmacol. Chemother. 21, 127-136.

Noble RL. (1990) The discovery of the vinca alkaloidschemotherapeutic agents against cancer. Biochem. Cell Biol. 68, 1344-1351.

Ojewole JA. (2005) Antinociceptive, anti-inflammatory and antidiabetic effects of Bryophyllum pinnatum (Crassulaceae) leaf aqueous extract. J. Ethnopharmacol. 99, 13-19.

Okerulu IO, Ani CJ (2001). The phytochemical analysis and antibacterial screening of extracts of Tetracarpidium Conophorum. J. Chem. Soc. Nigeria 26, 53-57.

Owoyele VB, Oloriegbe YY, Balogun EA, Soladoye AO. (2005) Analgesic and anti-inflammatory properties of Nelsonia canescens leaf extract. J. Ethnopharmacol. 99, 153-156.

Ozaki Y, Sekita S, Soedigdo S, Harada M. (1989) Antiinflammatory effect of Graptophyllum pictum (L.) Griff. Chem. Pharm. Bull. 37, 2799-2802.

Rosin MP, Anwar WA, Ward AJ. (1994) Inflammation, chromosomal instability and cancer: the Schistosomiasis model. Can. Res. 54, 1929S-1933S.

Schmidt L, Joker D. (2000) Swietenia mahagoni (L.) Jacq. In: Danida Forest Seed Centre. No. 18. 
Sertie JA, Woisky RG, Wiezel G, Rodrigues M. (2005) Pharmacological assay of Cordiaverbenacea V: oral and topical anti-inflammatory activity, analgesic effect and fetus toxicity of a crude leaf extract. Phytomed. 12, 338-344.

Sparg SG, Light ME, Staden Jvan. (2004) Biological activities and distribution of plant saponins. J. Ethnopharmacol. 94, 219-243.

Subapriya R, Nagini S. (2005) Medicinal properties of neem leaves: a review. Curr. Med. Chem. - Anticancer
Agents 5, 149-156.

Thun M, Namboodiri MM, Heath CW Jr. (1991) Aspirin use and reduced risk of fatal colon cancer. New Eng. J. Med. 325, 1593-1596.

Wang XW, Xie H. (1999) Alkaloids of Chinese Aconitum plants. Drug Future 24, 877-882.

Winter CA, Risely EA, Nuss GW. (1992) Carrageenininduced edema in hind paw of the rat as an assay for anti-inflammatory drugs. Proc. Soc. Expt. Biol. Med. 111, 544-547. 